\title{
Molecular characterization of marine bacterial isolates of Visakhapatnam coast-efficacy in dye decolorization and bioremediation of cadmium
}

\author{
Teja Mandragutti ${ }^{1 *}$, Muni Kumar Dokka², Bindiya Panchagnula ${ }^{1}$ and Sudhakar Godi ${ }^{3}$
}

\begin{abstract}
Background: Microbial community is one of the diversified communities of the marine environment. Studies have shown that microorganisms isolated from the marine environment are metabolically active and have adapted to life in the ocean. The marine microorganisms use various survival strategies to combat heavy metal stress and decolorization of various textile dyes, thus playing an important role in the bioremediation of cadmium and degradation of textile dyes. The present study deals with the isolation and 16S rRNA molecular characterization of M3 and M8 bacterial strains isolated from marine water samples collected from Visakhapatnam harbor. M3 and M8 isolates were also checked for their efficacy in the removal of cadmium and decolorization of various textile dyes from the environment.

Results: The water sample was subjected to tube dilution method to isolate bacterial strains, and ten different isolates were screened. The biochemical tests were performed for the isolates to prove their validity and 16S rRNA molecular sequencing and phylogenetic analysis for species identification. Out of interest, two bacterial strains, namely, M3 and M8 were subjected to $16 \mathrm{~S}$ rRNA molecular sequencing and phylogenetic analysis and were identified as Bacillus subtilis and Pseudomonas resinovorans. The two bacterial strains showed promising dye degradation property when checked with nine different textile dyes of wavelength ranging from 400 to $600 \mathrm{~nm}$ and removal of cadmium from the growth medium.
\end{abstract}

Conclusion: The present study demonstrates the isolates M3 and M8 to be potential strains having dye decolorization and bioremediation of cadmium applications.

Keywords: Bacillus subtilis, Pseudomonas resinovorans, 16S rRNA, Phylogenetic analysis, Bioremediation

\section{Background}

The marine environment covers approximately $70 \%$ of earth surface and contains vast biological diversity which accounts for more than $90 \%$ of the whole biosphere and offers a great source of novel compounds [1]. The marine environment is a prolific resource for the isolation of less exploited microorganisms and represents a largely

\footnotetext{
*Correspondence: tejaaron75@gmail.com

'Department of Biotechnology, Andhra University, Visakhapatnam 530 003, India

Full list of author information is available at the end of the article
}

untapped source for the isolation of new microorganisms [2]. Thus, marine ecosystems and coastal regions are particularly promising because of the rightly adapted species in the harsh environment. Bacteria from marine environment grow in extreme environmental conditions such as high pressure, low temperature, high salinity, and depletion of micronutrients [3]. Hence, the exploration of marine microorganisms from marine environment has led to the discovery of hundreds of microbes with biologically active compounds and versatile properties like bioremediation, biodegradation of textile dyes, 
and bioleaching. Marine microorganisms have become significant source of novel microbial products exhibiting antibacterial, anticancer, anti-viral, anti-coagulant, antiinflammatory, antioxidant, and cardioprotective properties [4]. Varied types of halophilic and halotolerant microbes have been isolated from broad range of aquatic environment [5]. Species-specific variability regions of $16 \mathrm{~S}$ rRNA gene sequence analysis is the most supportive for the classification of phylogenetic uniqueness in conformity to the phenotypic profiles for the identification of microbes [6].

The textile industry plays a crucial role in the global economy as well as in the daily life and simultaneously becoming one of the main sources of environmental pollution in the world in terms of quality and quantity [7]. The textile industry consumes a larger volume of water in which roughly $90 \%$ appear as wastewater [8]. Textile wastewater contains various types of dyes as major pollutants which not only is recalcitrant but also imparts intense color to the waste effluent [7]. Inappropriate dumping of textile wastewater causes serious environmental hazards that affect the aquatic organisms badly [9]. Inappropriate effluent disposal in aqueous ecosystems leads to reduction of sunlight penetration which in turn diminishes photosynthetic activity, resulting in acute toxic effects on the aquatic flora and fauna and dissolved oxygen concentration [10]. Increased biological oxygen demand (BOD) and chemical oxygen demand (COD) values of the dye effluent make it complicated to degrade and produce a toxic environment for aquatic biodiversity [11]. So, their treatment before releasing to the environment is so essential to minimize water pollution. Among different treatment processes, biotreatment has regarded the most efficient way in comparison with conventional physicochemical processes in the degradation of textile dyes [12]. Microbial decolorization and degradation is an environmentalfriendly and cost-competitive alternative to chemical decomposition processes [13]. The ability of microorganisms to carry out dye decolorization has recently received much attention as microbial decolorization of dyes is a cost-effective method for removing them from the environment [14]. Remediation of dyeing industry effluent by using microorganisms has proved to be the best solution, since numerous bacterial species including Bacillus, Pseudomonas, Enterobacter, Halobacter, and Aeromonas have been reported to exhibit incredible capability to decolorize and detoxify a wide range of dyes $[15,16]$.

Bioremediation is an innovative and promising technology available for removal of heavy metals and recovery of the heavy metals in polluted water and lands. Since microorganisms have developed various strategies for their survival in heavy metal-polluted habitats, these organisms are known to develop and adopt different detoxifying mechanisms such as biosorption, bioaccumulation, biotransformation, and biomineralization, which can be exploited for bioremediation either ex situ or in situ [15, 17]. Bioremediation has become one of the promising in situ technologies for the clean-up of environmental pollutants using microorganisms. Environmental pollution with heavy metals is increasing day by day due to urbanization and industrialization [18] and became a major global concern because of its toxicity and threat to human life and environment. Nowadays, the bioaccumulation of heavy metals in environment is a major warning to human life $[19,20]$.

Metals like copper, iron, manganese, and zinc are essential for life processes whereas others like cadmium, lead, nickel, and mercury have no physiological function but often results in harmful disorders at a higher concentration [21]. Many heavy metals are even non-degradable in nature and hence once released into the environment remain in circulation. Heavy metals containing industrial effluents lead to health hazards to plants, animals, aquatic life, and humans and thus increasing pressures on the flora and fauna [22]. Lead and cadmium which are major contaminants found in the environment are extremely poisonous to humans, animals, plants, and microbes which can damage cell membranes, alter functions of enzymes, and damage the structure of DNA. Microbes have evolved mechanisms such as active efflux or sequestration with proteins or insoluble compounds through which they may resist, detoxify, or metabolize these heavy metals. It is important to note that bioremediation technologies based on microbes are economically viable, costeffective, and environment friendly.

Cadmium (Cd) is identified as a major pollutant, nonessential metal, and is harmful to living organisms at relatively low concentrations, i.e., about $0.001-0.1 \mathrm{mg} / \mathrm{L}$ [23]. It is well known that cadmium is not involved directly in any known biological processes as a co-factor or activator, but is known to inhibit several enzyme activities, involved in the inhibition of DNA-mediated transformation in microorganisms and interference in the symbiosis between microbes and plants, as well as involved in plant predisposition to fungal invasion [24].

Hence, by considering the scope of marine bacteria and the less exploited nature of marine microorganisms, the present study has been taken up to isolate and characterize bacteria from marine water collected from Visakhapatnam harbor, and an attempt has been made to check the efficiency of M3 and M8 strains for their decolorization and bioremediation properties.

\section{Methods}

\section{Sample collection}

Marine water sample was collected in sterile bottles from Visakhapatnam harbor $\left(17.6958^{\circ} \mathrm{N}, 83.3025^{\circ} \mathrm{E}\right)$, 
Andhra Pradesh, and brought to laboratory and stored at $4^{\circ} \mathrm{C}$ until used for the isolation of bacteria.

\section{Isolation of bacteria}

Quantitative estimation of the viable bacteria was done by serial tube dilution method, plating, and colony count. The bacteria were isolated by spread plate method on nutrient agar medium, incubated at $37^{\circ} \mathrm{C}$ for $24 \mathrm{~h}$ to obtain colonies. The individual colonies were picked upon the basis of their macroscopic characters such as size, shape, surface appearance, texture, and color. These colonies were subjected to repeated streaking on nutrient agar plates/slants. The so obtained marine bacterial isolates were stored at $4^{\circ} \mathrm{C}$ for further studies.

\section{Morphological characterization of isolated bacteria}

Colony and cell morphology based on their color, shape, margin, elevation, surface, and arrangement of bacteria were studied.

\section{Gram staining}

The standard Gram staining procedure was followed for the morphological characterization of isolates [25].

\section{Biochemical characterization of isolated bacteria}

For the taxonomic identification, different biochemical tests were performed for all the ten isolates to check their metabolic activities following standard protocols [26].

\section{Identification of isolated bacteria by $16 \mathrm{~S}$ rRNA gene sequencing}

The isolates M3 and M8 were subjected to molecular characterization by16S rRNA sequencing. The DNA of the isolates was extracted using a standard protocol followed by Rohini et al. [27]. Confirmation of DNA was done using agarose gel electrophoresis on 1\% agarose gels. Fragment of $16 \mathrm{~S}$ rRNA gene was amplified by $27 \mathrm{~F}$ (5-GAGTTTGATCCTGGCTCA-3) and 1492 (R-TACG GYTACCTTGTTACGACTT) universal primers. PCR reaction was performed with the conditions such as initial denaturation at $94^{\circ} \mathrm{C}$ for $2 \mathrm{~min}, 35$ amplification cycles at $94^{\circ} \mathrm{C}$ for $45 \mathrm{~s}, 55^{\circ} \mathrm{C}$ for $60 \mathrm{~s}, 72^{\circ} \mathrm{C}$ for $60 \mathrm{~s}$, and a final extension at $72^{\circ} \mathrm{C}$ for $10 \mathrm{~min}$. The PCR amplicon was purified to remove contaminants. Forward and reverse DNA sequencing reaction of PCR amplicon was carried out with forward primer and reverse primers using BDT v3.1 Cycle sequencing kit on ABI 3730xl Genetic Analyzer. Consensus sequence of 16S rRNA gene was generated from forward and reverse sequence data using an aligner software.

\section{Construction of phylogenetic tree}

The 16S rRNA gene sequence of the two isolates was used to carry out BLAST with the database of NCBI Genbank. Based on maximum identity score, first ten sequences were selected and aligned using multiple alignment software program Clustal W. Distance matrix was generated, and the phylogenetic tree was constructed using MEGA 7.

\section{Applications of M3 and M8 bacterial strains Decolorization of dye compounds}

The two isolates were grown in $100 \mathrm{ml}$ minimal salt medium (MSM) containing selected dye compounds in a conical flask at $25^{\circ} \mathrm{C}$ and continuous shaking at $100 \mathrm{rpm}$. The composition of MSM is yeast extract $(1 \mathrm{~g} / \mathrm{L})$, $\left(\mathrm{NH}_{4}\right)_{2} \mathrm{SO}_{4}(2.5 \mathrm{~g} / \mathrm{L}), \mathrm{KH}_{2} \mathrm{PO}_{4}(13.3 \mathrm{~g} / \mathrm{L}), \mathrm{Na}_{2} \mathrm{HPO}_{4}(21.6 \mathrm{~g} /$ $\mathrm{L})$, and glucose $(1.25 \mathrm{~g} / \mathrm{L})$. The experiment was carried out using $50 \mathrm{mg}$ of each dye (Trypan blue, Methyl red, Neutral red, Congo red, Bromophenol blue, Coomassie brilliant blue, and Gentian violet) in $1 \mathrm{~L}$ of MSM separately. The isolates were inoculated in the sterile liquid minimal media in conical flasks and incubated at room temperature using shake-flask method. Samples were withdrawn at the intervals of $12 \mathrm{~h}, 24 \mathrm{~h}, 48 \mathrm{~h}, 72 \mathrm{~h}$, and 96h during the incubation and checked for decolorization of dye compounds using spectrophotometric analysis. A small aliquot of the media was extracted in sterile conditions. The aliquot was subjected to centrifugation at $10,000 \mathrm{rpm}$ for $5 \mathrm{~min}$. The supernatant was collected, and the absorbance was noted using the sterile uninoculated media without dye as a blank. The absorbance for different dyes was noted at their respective wavelengths.

The decolorization of the media indicates the degradation of the dye by the bacteria.

The efficiency of degradation of the dye can be calculated using the following formula:

$$
\% \text { Degradation }=\frac{\left(\mathrm{A}_{0}-\mathrm{A}_{\mathrm{t}}\right)}{\mathrm{A}_{0}} \times 100
$$

where $A_{0}$ is the initial absorbance of the media and $A_{t}$ is the absorbance of the media at the interval of " $\mathrm{t}$ " time.

\section{Cadmium removal capacity}

The isolated strains, M3 and M8, were checked for their cadmium removal capacity from the growth medium, Luria Bertani broth containing 100 휄 $\mathrm{g} / \mathrm{ml}$ of the cadmium. During the growth period, $1 \mathrm{ml}$ of each bacterial culture sample was removed into Eppendorf tubes after every $4 \mathrm{~h}$ until $24 \mathrm{~h}$ and centrifuged at $6000 \mathrm{rpm}$ for $15 \mathrm{~min}$. An extra sample without the addition of bacterial culture was taken as control. The supernatants were collected and stored at $4{ }^{\circ} \mathrm{C}$ for the cadmium analysis. The 
cadmium concentrations in the supernatants were analyzed using Atomic Absorption Spectrometer (Agilent Technologies Pvt, Ltd., Australia) at $228.8 \mathrm{~nm}$ with a cadmium hollow cathode lamp. The percentage of cadmium concentration in the growth medium was calculated at every $4 \mathrm{~h}$ intervals. The optimal density of each sample was also measured at $600 \mathrm{~nm}$ to compare the growth rate of bacteria with the cadmium removal capacity [28].

\section{Results}

Isolation of bacteria and morphological characterization of bacteria

A total of ten different bacterial colonies were isolated from marine water sample on the basis of unique colonial characteristics on nutrient agar medium. Morphological and colony characteristics for the isolated bacteria were observed and tabulated (Table 1). All the ten bacterial isolates exhibited different morphological and colonial characteristics.

\section{Biochemical characterization of bacterial isolates}

For taxonomic identification, the isolates were subjected to a series of biochemical tests which includes mannitol salt agar, methyl red test, Voges-Proskauer test, Indole test, citrate utilization test, oxidase test, urease test, gelatine liquefaction test, catalase activity, $\mathrm{H}_{2} \mathrm{~S}$ production, motility, starch hydrolysis, hemolysis, and carbohydrate fermentation tests, and the results are shown in Table 2. The isolate differed in acid production, $\mathrm{H}_{2} \mathrm{~S}$ production, methyl red test, Voges-Proskauer test, hemolysis, and other tests. Morphological and biochemical characteristics including the colony characters of the ten isolates were not identical which proved that the structure and functions of the isolates were different. Of all the ten isolates, M3 and M8 (Fig. 1) were chosen out of interest and further selected for molecular characterization by $16 \mathrm{~S}$ rRNA sequencing and phylogenetic analysis. The morphological and physiological characteristics of M3 and M8 were compared with the data from Bergey's Manual of Determinative Bacteriology, and M3 was found to be a facultative anaerobe, motile, and grampositive rod and M8 a facultative anaerobe, motile, and gram-negative rod.

\section{Extraction of DNA, PCR amplification, and 16SrRNA gene sequencing of $M 3$ and $M 8$ isolates}

DNA isolation, PCR amplification of 16SrRNA gene sequencing, and sequencing of rRNA fragment were done according to sarkosyl method [29]. DNA was isolated from the isolates, and the purity was evaluated on $1.0 \%$ agarose gel. A single band of high-molecular weight DNA has been observed (Fig. 2A).
A molecular approach was used to establish and support the identification of the isolates. The 16S rRNA gene has become a reliable tool for the identification and classification of bacteria. 16S rRNA gene studies are necessary to achieve unambiguous identification at the species level. Fragment of $16 \mathrm{~S}$ rRNA gene was amplified by $27 \mathrm{~F}$ and $1492 \mathrm{R}$ primers, and a single discrete PCR amplicon band of $1500 \mathrm{bp}$ was observed when resolved on agarose gel for both the isolates (Fig. 2B). The PCR amplicon was purified to remove contaminants. Forward and reverse DNA sequencing reaction of PCR amplicon product was carried out with forward primer and reverse primers using BDT v3.1 Cycle sequencing kit on ABI 3730xl Genetic Analyzer. Consensus sequence of $16 \mathrm{~S}$ rRNA gene was generated from forward and reverse sequence data using an aligner software. The 16S rRNA gene sequence was used to carry out BLAST with the database of NCBI Genbank. 16S rRNA sequences of both the isolates M3 and M8 were submitted to NCBI GenBank and got the accession numbers for both the isolates-M3 (Bacillus subtilis MZ047611) and M8 (Pseudomonas resinovorans MZ047610).

\section{Phylogenetic analysis}

The 16S rRNA gene sequences of both the isolates were subjected to BLAST online tool in the database of NCBI Genbank. Phylogenetic analysis was performed based on maximum identity scores; first ten sequences were selected and aligned using multiple alignment software program Clustal W. The molecular and phylogenetic analysis of 16SrRNA gene sequences revealed the two isolates, M3 and M8, showed identity to Bacillus subtilis (98.24\%) and Pseudomonas resinovorans (98.17\%) respectively. Distance matrix was generated, and the phylogenetic tree was constructed using MEGA 7 (Fig. 3a and b).

The evolutionary history was inferred by using the maximum likelihood method based on the Kimura 2parameter model [30]. Evolutionary analyses were conducted in MEGA7 [31]. The bootstrap consensus tree inferred from 1000 replicates is taken to represent the evolutionary history of the taxa analyzed [32].

\section{Applications of M3 and M8 isolates Decolorization of dyes}

The isolates M3 (Bacillus subtilis) and M8 (Pseudomonas resinovorans) were tested for their ability to decolorize $50 \mathrm{mg} / \mathrm{L}$ of seven dyes, namely, Trypan blue, Methyl red, Neutral red, Congo red, Bromophenol blue, Coomassie brilliant blue, and Gentian violet. The dye concentration was decreased with increase in period of time for all the dyes. The percent degradation of various dyes by the two isolates is shown in Figs. 4 and 5 . Complete decolorization (100\%) of the dye Congo red was achieved by the isolate M8, and the isolate M3 


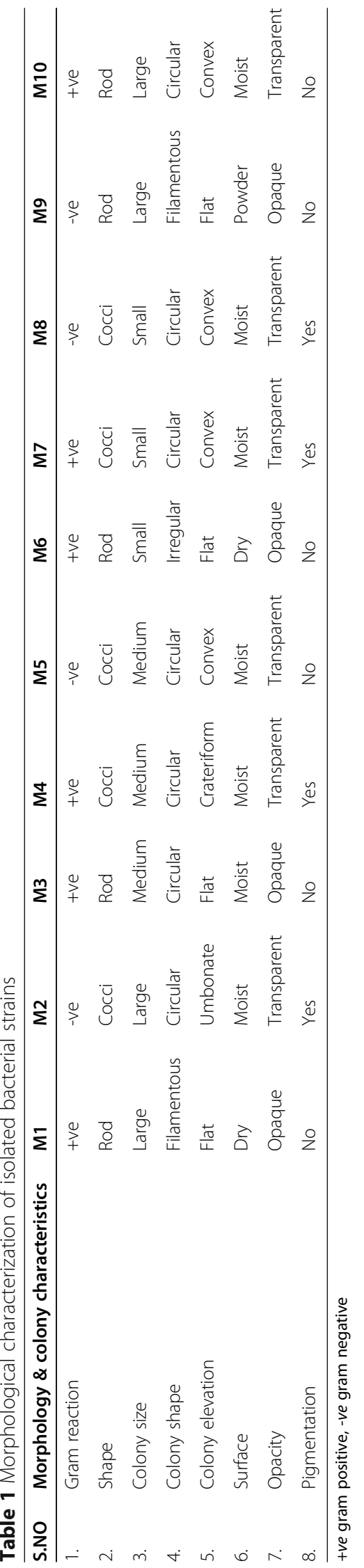


Table 2 Biochemical characterization of isolated bacterial strain

\begin{tabular}{|c|c|c|c|c|c|c|c|c|c|c|c|}
\hline S. No & Name of the Test & M1 & M2 & M3 & M4 & M5 & M6 & M7 & M8 & M9 & M10 \\
\hline 1. & Catalase activity & - & + & + & + & + & + & - & + & - & + \\
\hline 2. & Hemolysis & $a$ & A & $\beta$ & Y & $a$ & $\beta$ & $\beta$ & $\beta$ & $a$ & Y \\
\hline 3. & Oxidase & + & + & + & - & + & + & - & + & - & - \\
\hline 4. & Urease & + & - & - & - & - & - & - & - & - & - \\
\hline 5. & Methyl red & + & + & + & + & + & + & + & - & + & + \\
\hline 6. & Voges-Proskauer reaction & + & - & - & - & - & - & - & - & - & - \\
\hline 7. & Indole & - & - & - & - & - & - & - & - & - & - \\
\hline 8. & Starch hydrolysis & + & + & + & + & + & + & + & + & + & + \\
\hline 9. & Gelatin liquefaction & + & + & + & + & + & + & + & + & + & + \\
\hline 10. & Motility & M & NM & M & NM & M & NM & M & M & M & NM \\
\hline 11. & Nitrate reduction & + & - & + & + & + & + & - & + & - & + \\
\hline 12. & $\mathrm{H}_{2} \mathrm{~S}$ production & + & + & + & + & + & + & $\begin{array}{l}+ \\
-\end{array}$ & - & + & + \\
\hline 13. & Citrate utilization & + & - & - & + & - & - & + & - & + & + \\
\hline \multirow[t]{7}{*}{14.} & Carbohydrate utilization test & & & & & & & & & & \\
\hline & Sucrose & A & A & A & $A / G$ & A & A & A & A & A & A \\
\hline & Maltose & $A$ & A & A & A & $A / G$ & A & A & - & $A$ & A \\
\hline & Glucose & A & A & - & A & $A$ & A & $A$ & $A / G$ & A & $A / G$ \\
\hline & Lactose & $A$ & - & A & A & $A / G$ & - & A & - & A & A \\
\hline & Mannitol & $A$ & - & - & A & - & - & - & - & - & A \\
\hline & Mannose & - & - & $A$ & $A$ & $A$ & $A$ & $A$ & & $A$ & $A$ \\
\hline
\end{tabular}

+ positive, - negative, $M$ motile, $N M$ non-motile, $A$ acid producer, $G$ gas producer, $A / G$ acid and gas producer

attained $95 \%$ of decolorization in 2 days of incubation. The isolate M3 decolorized Trypan blue, Methyl red, Neutral red, Bromophenol blue, Coomassie brilliant blue, and Gentian violet with 72\% (96h), 78\% (96h), 68\% (96), 70\% (48h), 62\% (72), and 72\% (48h) respectively. On the other hand, isolate M8 also decolorized Trypan blue, Methyl red, Neutral red, Bromophenol blue, Coomassie brilliant blue, and Gentian with $80 \%$ (96h), 93\% (48h), 86\% (48h), 78\% (24h), 60\% (72h), and 94\% (24h) respectively.

\section{Cadmium removal capacity of $M 3$ and $M 8$ isolates}

The cadmium removal capacity of the isolates M3 and M8 is shown in Figs. 6 and 7. The lag phase was observed during the initial $0-4 \mathrm{~h}$ which was another sign of the cadmium toxicity to both the isolates. In the lag phase, isolate M3 removed only $2.08 \%$ of the cadmium whereas the isolate M8 removed $4.32 \%$ of the cadmium from the medium. After that, in log phase $(8-16 \mathrm{~h})$, isolate M8 removed the maximum amount of the cadmium which is about $84.70 \%$, and the isolate M3 removed

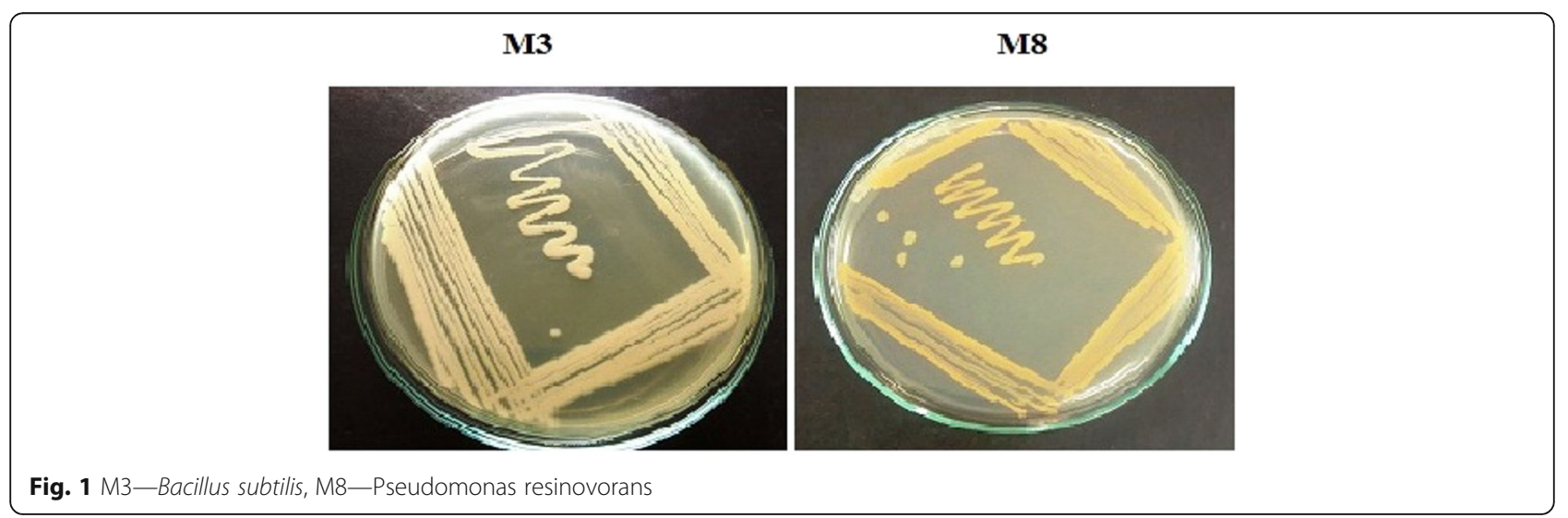




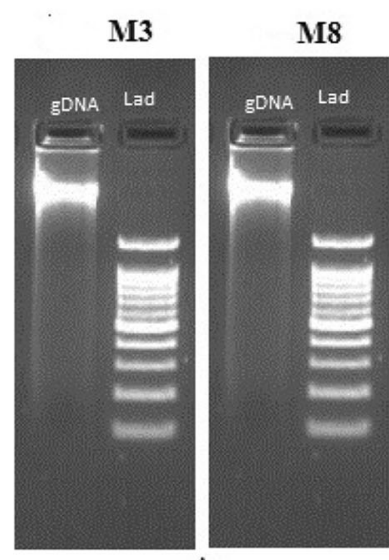

A

Fig 2a

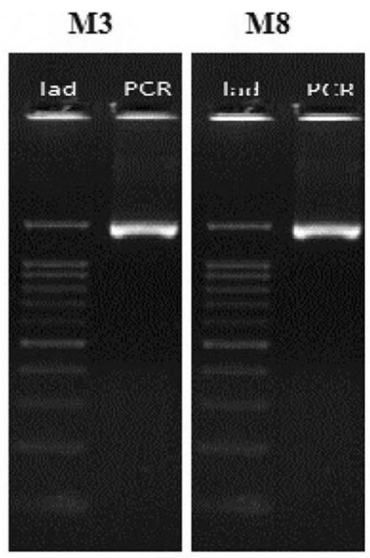

B

Fig $2 b$

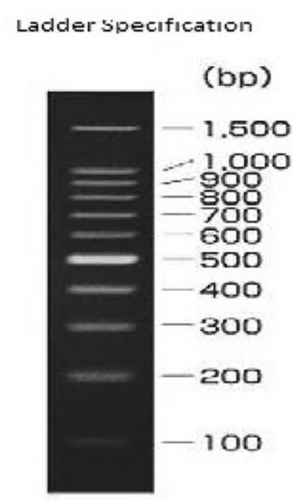

\section{A - Amplification of Genomic DNA}

$B$ - Amplification of $16 \mathrm{~S}$ rRNA gene

Fig. 2 A Amplification of genomic DNA of M3 and M8 isolates. B Amplification of 165 rRNA gene of M3 and M8 isolates

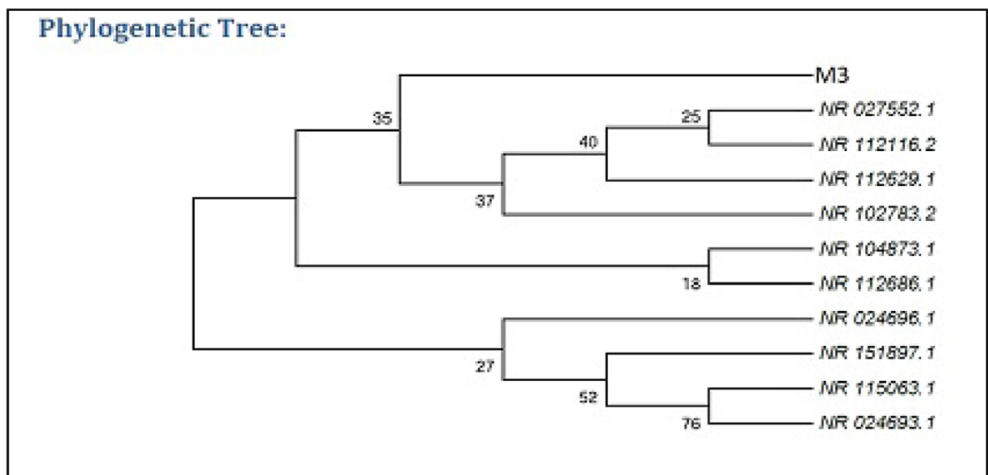

Fig. 3a

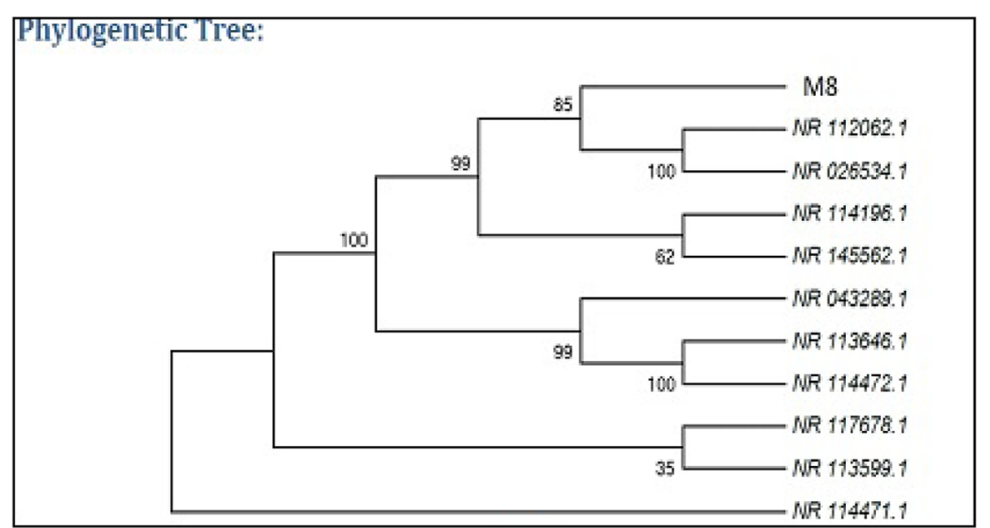

Fig. 3b

Fig. 3 a Phylogenetic relationship of isolated strain M3. The tree is constructed using 165 rRNA sequence by maximum likelihood method. b Phylogenetic relationship of isolated strain M8. The tree is constructed using 165 rRNA sequence by maximum likelihood method 


\section{Decolourization of dyes by Bacillus subtilis}

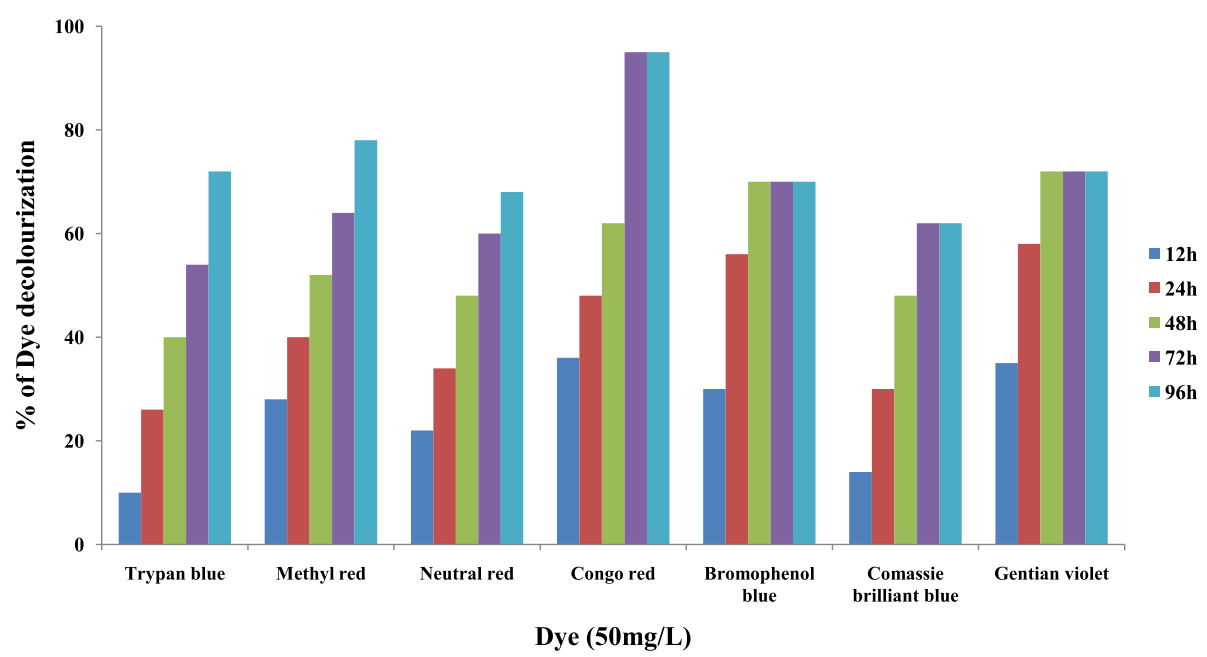

Fig. 4 Decolorization of different dyes by Bacillus subtilis (M3)

$74.14 \%$ because in this phase bacteria rapidly divide with time, so bioaccumulation of the cadmium also increased. The percentage of the cadmium bioaccumulation by both isolates M3 and M8 was increasing from the beginning up to $16 \mathrm{~h}$. After $16 \mathrm{~h}$, a slight reduction in cadmium removal was observed from the medium at stationary phase for both the isolates.

\section{Discussion}

Marine microorganisms have developed unique metabolic and physiological capabilities that not only ensure survival in extreme habitats but also offer the potential for the production of metabolites [33, 34]. Marine microorganisms have significant osmotic tolerance leading to their capability to survive at higher salt concentration [35].
Microorganisms are considered to be the best indicators of changes in environmental conditions and are sensitive to low concentration of heavy metals but rapidly adapt to the specific habitat conditions [36]. Nowadays, bioremediation has become one of the promising approaches for the removal of toxic textile synthetic dyes which were expelled from textile, paper, printing, and mineral processing industries. It is a well-known fact that several microorganisms including bacteria, fungi, yeasts, and algae can completely decolorize many dyes [37].

In the present study, ten bacterial strains were isolated from marine water collected from Visakhapatnam harbor by serial tube dilution method. All the isolates showed different morphological and colonial characteristics on nutrient agar medium. Biochemical characterization was done

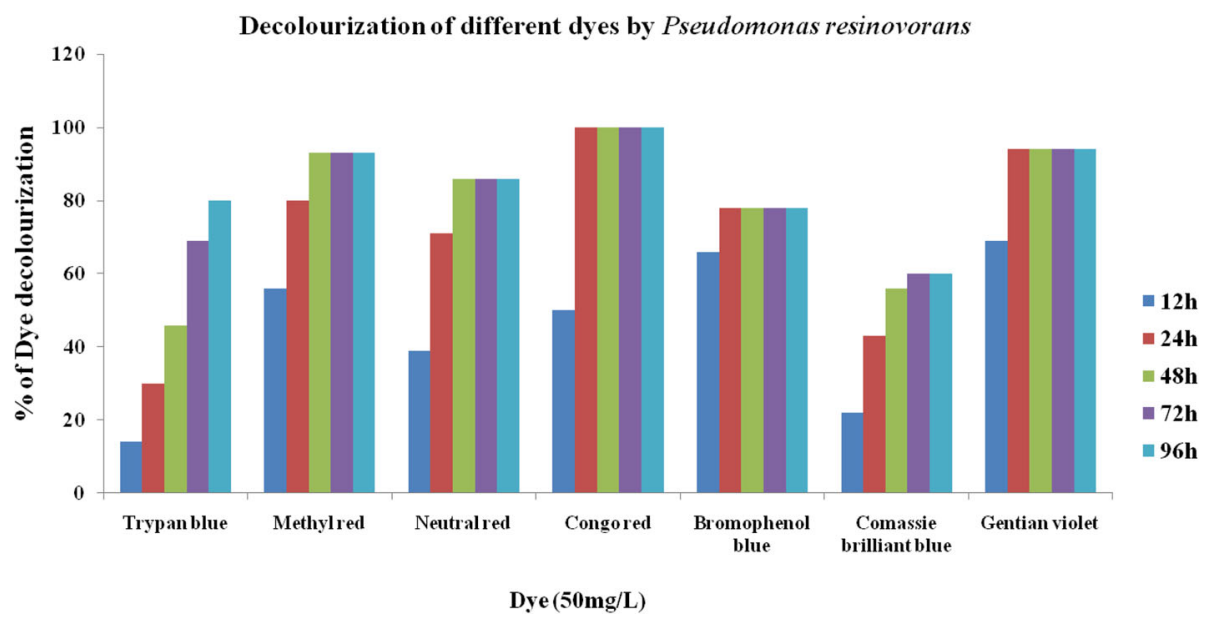

Fig. 5 Decolorization of different dyes by Pseudomonas resinovorans (M8) 


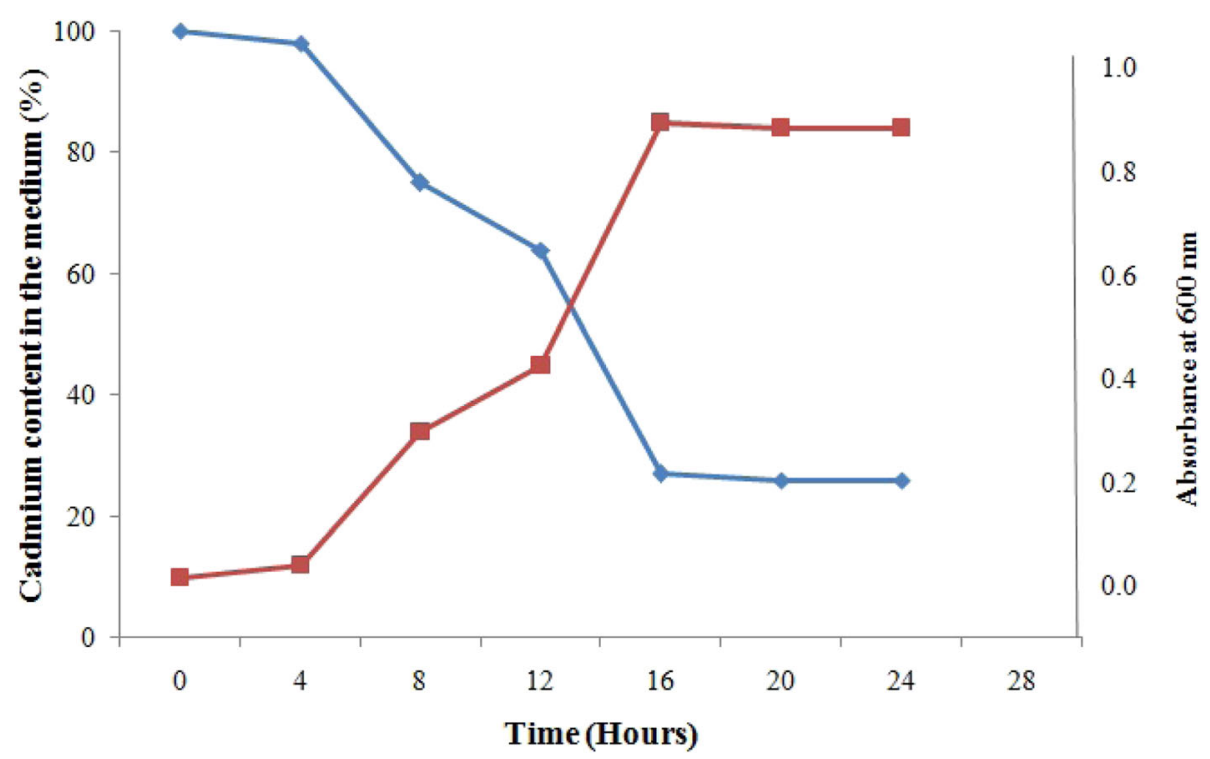

Fig. 6 Removal of cadmium by Bacillus subtilis (M3)

for all the isolates, and they differed in their biochemical characteristic properties. The morphological and biochemical characteristics of M3 and M8 were compared with the data from Bergey's Manual of Determinative Bacteriology, and M3 was found to be a facultative anaerobe, motile, and gram-positive rod and M8 a facultative anaerobe, motile, and gram-negative rod. Isolates M3 and M8 were selected for molecular characterization by $16 \mathrm{~S}$ rRNA sequencing and phylogenetic analysis. Molecular characterization by $16 \mathrm{~S}$ rRNA gene sequence analysis is a cost-effective tool to identify simpler to complex microbial strains at species level. The phylogenetic analysis was performed for both the isolates using $16 \mathrm{~S}$ rRNA gene sequences to identify microbial strains at species level. The amplified gene sequences were aligned with closely related strain sequences retrieved from NCBI database obtained by BLAST search.

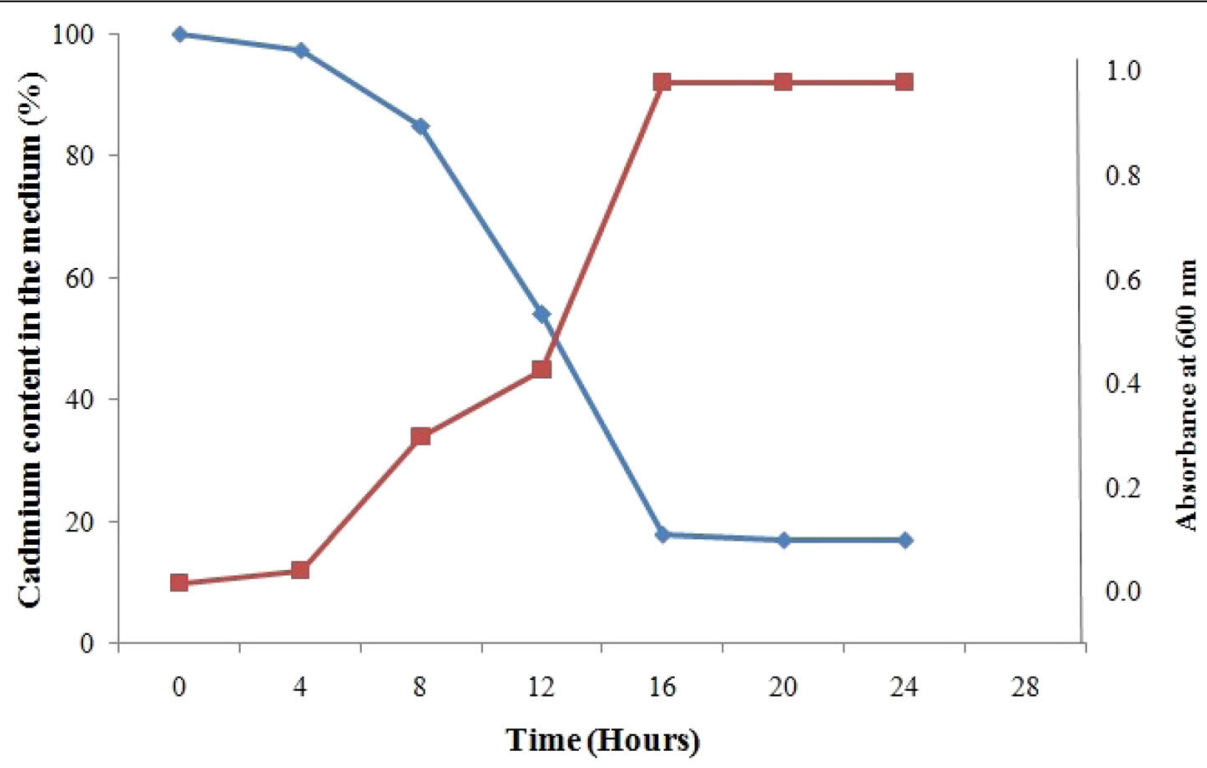

$\sim$ Cadmium removal (\%)

Absorbance

Fig. 7 Removal of cadmium by Pseudomonas resinovorans (M8) 
The molecular characterization and phylogenetic analysis of the gene sequences by maximum likelihood method revealed that the two isolates, M3 and M8, showed identity to Bacillus subtilis (98.24\%) and Pseudomonas resinovorans (98.17\%) respectively. Ivanova et al. [38] reported taxonomically characterized Bacillus strains isolated from marine waters of the Pacific Ocean. Several Bacillus sp. have been reported from marine environment by molecular characterization of $16 \mathrm{~S}$ rRNA gene sequence [39, 40]. 16S rRNA gene sequencing was also allowed in the identification in the several Pseudomonas sp. [41].

The isolates M3 and M8 effectively decolorized 50mg/L of seven textile dyes, namely, Trypan blue, Methyl red, Neutral red, Congo red, Bromophenol blue, Coomassie brilliant blue, and Gentian violet. Interestingly, M3 has completely (100\%) decolorized Congo red whereas M8 decolorized 95\% of the dye. Sharma et al. [42] reported high dye decolorization ability of Bacillus sp., Alcaligenes sp., and Aeromonas sp., isolated from soil and sludge samples.

The decolorizing Bacillus and Pseudomomas isolates were also reported from the textile effluent samples [43]. Kumar and Sawhnei [44] reported that Bacillus subtilis-RA29 efficiently degraded Congo red (95.6\%) at $37^{\circ} \mathrm{C}$. Microorganisms can be used to completely degrade the dyes because they reduce the dyes by secreting enzymes such as laccase, azoreductase, peroxidase, and hydrogenase [45]. Decolorization of dyes may take place either by adsorption onto the microbial biomass or biodegradation of dyes by the cells [46]. The possibility of using novel microbial consortium for biological treatment of disreputable dyeing effluents has been reported by Karim et al. [47].

The natural marine bacterial isolates have got tremendous potential to tolerate, sequester, and remove toxic metal pollutants from the ambient environment. Therefore, the present study focused to check the capability of marine bacterial isolates M3 and M8 with reference to their role in the removal of cadmium from the growth medium. The M8 effectively removed the maximum amount of cadmium from the growth medium to about $84.70 \%$, and M3 removed $74.14 \%$ of cadmium from the growth medium. The findings of the study revealed that both the isolates can be recommended in the bioremediation of cadmium from the pollutant environment.

Heavy metal-resistant microorganisms play an important role in the bioremediation of heavy metalcontaminated environment $[48,49]$. Response to varying concentrations of cadmium on Bacillus sp. isolated from Indian coastal waters was reported by Nair et al. [50]. Several studies have reported the ability of gramnegative bacteria to resist and accumulate cadmium ions [51]. Pseudomonas aeruginosa biomass was reported and effective bio adsorbent for the removal and recovery of cadmium from polluted water [52].

\section{Conclusions}

The current study has been focused on the isolation and characterization of bacterial isolates, M3 and M8 from the marine water of Visakhapatnam harbor. The isolates were characterized by using biochemical test and $16 \mathrm{~S}$ rRNA molecular sequencing followed by phylogenetic analysis. The results of molecular characterization revealed that the isolates M3 have $98.24 \%$ identity to $B a$ cillus subtilis and M8 have 98.17\% towards Pseudomonas resinovorans. The isolates effectively decolorized textile dyes and removed cadmium from the growth medium. Overall results in the present suggest that isolates M3 and M8 could be used in the bioremediation of heavy metals from the pollutant environment and also in the degradation of textile dyes. Further studies are needed to support the experimental work in studying the molecular mechanism of dye decolorization by the isolates M3 and M8. The eco-friendly bioremediation of cadmium from the medium by M3 and M8 isolates offer a great choice to eliminate toxic cadmium permanently from the environment and consequently supports their potential as bioremediation agents in polluted environments indicating the potential of isolates as biosorbent for removal of high concentration of heavy metals from wastewater and industrial effluents.

\section{Supplementary Information}

The online version contains supplementary material available at https://doi. org/10.1186/s43141-021-00189-0.

Additional file 1. Supplementary file 1

Authors' contributions

All the authors read and approved the manuscript for submission. MT designed the concept, performed the experiments and initially drafted the research article. GS interpreted and supervised some of the experimental works. DMK contributed in the experimental works and drafting of the research article. PB contributed in the experimental works.

\section{Competing interests}

The authors declared that they have no competing interests.

\section{Author details}

${ }^{1}$ Department of Biotechnology, Andhra University, Visakhapatnam 530 003, India. '2Department of Biochemistry, Andhra University, Visakhapatnam 530 003, India. ${ }^{3}$ Department of Human Genetics, Andhra University,

Visakhapatnam 530 003, India.

Received: 12 March 2021 Accepted: 1 June 2021

Published online: 16 June 2021

References

1. Aneiros A, Garatei A (2004) Bioactive peptides from marine sources: pharmacological properties and isolation procedures. J Chromatogr B Anal Technol Biomed Life Sci 15:41-53

2. Bredholt H, Fjaervik E, Jhonsen G, Zotechev SB (2008) Actinomycetes from sediments in the Trondhe in Fjord, Norway: diversity and biological activity. J Mar Drugs 6(1):12-24. https://doi.org/10.3390/md6010012

3. Valli S, Sugasini SS, Aysha OS, Nirmala P, Kumar PV, Reena A (2012) Antimicrobial potential of actinomycetes species isolated from marine environment. Asian Pac J Trop Biomed 45:469-474 
4. Jensen PR, Gontang E, Mafnas C, Mincer TJ, Fenical W (2005) Culturable marine actinomycetes diversity from tropical Pacific Ocean sediments. Appl Environ Microbiol 7(7):1039-1048. https://doi.org/10.1111/j.1462-2920.2005. 00785.x

5. Xiang WL, Guo JH, Feng W, Huang M, Chen H, Zhao J, Zhang J, Yang ZR, Sun Q (2008) Community of extremely halophilic bacteria in historic Dagong brine well in southwestern China. World J Microbiol Biotechnol 24(10):2297-2305. https://doi.org/10.1007/s11274-008-9744-0

6. Mignard S, Flandrois JP (2006) $16 \mathrm{~S}$ rRNA sequencing in routine bacterial identification a 30-month experiment. J Microbiol Methods 67(3):574-558. https://doi.org/10.1016/j.mimet.2006.05.009

7. Mondal P, Baksi S, Bose D (2017) Study of environmental issues in textile industries and recent wastewater treatment technology. World Sci News 61: 98-109

8. Verma AK, Dash RR, Bhunia P (2012) A review on chemical coagulation/ flocculation technologies for removal of colour from textile wastewaters. J Environ Manag 93(1):154-168. https://doi.org/10.1016/j.jenvman.2011.09.012

9. Subhathra M, Prabakaran V, Kuberan T, Balamurugan I (2013) Biodegradation of Azo dye from textile effluent by Lysini bacillus sphaericus. Sky J Soil Sci Environ Manag 2:1-11

10. MuhdJulkapli N, Bagheri S, Bee Abd Hamid S (2014) Recent advances in heterogeneous photocatalytic decolorization of synthetic dyes. Sci World J 2014:1-25

11. Robinson T, McMullan G, Marchant R, Nigam P (2001) Remediation of dyes in textile effluent: a critical review on current treatment technologies with a proposed alternative. Bioresour Technol 77(3):247-255. https://doi.org/10.1 016/50960-8524(00)00080-8

12. McMullan G, Meehan C, Conneely A, Kirby N, Robinson T, Nigam P, Banat IM, Marchant R, Symth WF (2001) Microbial decolourization and degradation of textile dyes. Appl Microbiol Biotechnol 56:81-87

13. Verma PD, Madamwar (2003) Decolourization of synthetic dyes by a newly isolated strain of Serratia marcescens. World J Microbiol Biotechnol 19(6): 615-618. https://doi.org/10.1023/A:1025115801331

14. Kalyani DC, Patil PS, Jadhav JP, Govindwar SP (2008) Biodegradation of reactive textile dye Red BLI by an isolated bacterium Pseudomonas sp SUK1. Bioresour Technol 99:4635-4641

15. Telke AA, Kalyani DC, Jadhav JP, Govindwar SP (2008) Kinetics and mechanism of reactive red 141 degradation by a bacterial isolate Rhizobium radiobacter MTCC 8161. Acta Chim Slov 55:320-329

16. Feng J, Cerniglia CE, Chen H (2012) Toxicological significance of azo dye metabolism by human intestinal microbiota. Front Biosci 1(4):568-586

17. Malik A (2004) Metal bioremediation through growing cells. Environ Int 30(2):261-278. https://doi.org/10.1016/j.envint.2003.08.001

18. Mythili K, Karthikeyan B (2011) Bioremediation of chromium [Cr (VI)] in tannery effluent using Bacillus spp. and Staphylococcus spp. Int J Pharm Biol Arch 2(5):1460-1463

19. Yigit S, Ahmet A (2006) Concentration of heavy metals in food web of Lake Egidir. Turk J Environ Biol 27:475-478

20. Hooda V (2007) Phytoremediation of toxic metals from soil and waste water. J Environ Biol 28:367-379

21. Lenin M, Kumar MS, Mycin TR (2014) Effect of sago factory effluent on seed germination and seedling growth of gingelly (Sesamumindicum $L$ ) varieties. Int J Life Sci Biotechnol Pharma Res 3(1):151-160

22. Robin R, Muduli P, Vardhan K, Ganguly D, Abhilash K (2012) Heavy metal contamination and risk assessment in the marine environment of Arabian Sea, along the Southwest coast of India. Am J Chem 2:191-208

23. Tang XY, Zhu YG, Cui YS, Duan J, Tang L (2006) The effect of ageing on the bioaccessibility and fractionation of cadmium in some typical soils of China. Environ Int 32(5):682-689. https://doi.org/10.1016/j.envint.2006.03.003

24. KabataPendias A, Pendias H (2001) Trace elements in soils and plants. CRC Press, London

25. Bartholomew JW, Mittwer T (1952) The gram stain. Bacteriol Rev Mar 16(1):1-29

26. Cappuccino JG, Sherman N (2005) Microbiology a laboratory manual, 7th edn. Pearson Education Inc, San Francisco, pp 143-189

27. Rohini D, Phadnis S, Rawal SK (2006) Synthesis and characterization of PHB from Bacillus thuringiensis R1. Indian J Biotechnol 5:276-283

28. Zeng XX, Tang JX, Liu XD, Jiang P (2009) Isolation, identification and characterization of cadmium resistant Pseudomonas aeruginosa strain E1. J Cen South Univ Technol 16:416-421

29. Maniatis T, Fritsch EF, Sambrook J (1982) Molecular cloning a laboratory manual. Cold Spring Harbour Laboratory Press, New York
30. Kimura M (1980) A simple method for estimating evolutionary rate of base substitutions through comparative studies of nucleotide sequences. J Mol Evol 16:111-120

31. Kumar S, Stecher G, Tamura K (2016) MEGA7: molecular evolutionary genetics analysis version 7.0 for bigger datasets. Mol Biol Evol 33(7):18701874

32. Felsenstein J (1985) Confidence limits on phylogenies: an approach using the bootstrap. Evolution 39(4):783-791. https://doi.org/10.1111/j.1558-5646.1 985.tb00420.x

33. Chellaram C, Edward JKP (2009) Improved recoverability of bacterial strains from soft coral, Lobophytum sp for antagonistic activity. J Pure Appl Microbiol 3(2):649-654

34. Prem AT, Chellaram C, Shanthini CF, Sivakumar R (2013) Analysis on inducement of antibiotic production in marine bacteria. J Chem Pharm Res 5(5):236-240

35. Poli A, Anzelmo G, Nicolaus B (2010) Bacterial exopolysaccharides from extreme marine habitats: production, characterization and biological activities. Mar Drugs 8:1779-1802

36. Kamala KS, Lee KJ (2008) Metal tolerance and antibiotic resistance of Bacillus species isolated from Sunchon Bay Sediments, South Korea. Biotechnology 7(1):149-152. https://doi.org/10.3923/biotech.2008.149.152

37. Tripathi A, Srivastava SK (2011) Ecofriendly treatment of Azo dyes: bio decolorization using bacterial strains. Int J Biosci Biochem Bioinformatics 1(1):150-156

38. Ivanova EP, Vysotskii MV, Svetashev VI, Nedashkovskaya OI, Gorshkova NM, Mikhailov W, Yumoto N, Shigeri Y, Taguchi T, Yoshikawa S (1999) Characterization of Bacillus strains of marine origin. Int Microbiol 2:267-271

39. Abushady HM, Bashandy AS, Aziz NH, Ibrahim HMM (2005) Molecular characterization of Bacillus subtilis surfactin producing strain and the factors affecting its production. Int J Agric Biol 7(3):337-344

40. Miranda CAC, Martins OB, Clementino MM (2007) Species-level identification of Bacillus strains isolates from marine sediments by conventional biochemical, 16S rRNA gene sequencing and inter-tRNA gene sequence lengths analysis. Antonie Van Leeuwenhoek 93(3):297-304. https://doi.org/1 0.1007/s10482-007-9204-0

41. Yojiro A, Kim H, Park J-Y, Wakabayashi H, Oyaizu H (2000) Phylogenetic affiliation of the pseudomonads based on 165 rRNA sequence. Int J Syst Evol Microbiol 50:1563-1589

42. Sharma DK, Saini HS, Singh H, Chimni SS, Chada BS (2004) Biological treatment of textile dye acid violet-17 by bacterial consortium in an upflow immobilized cell bioreactor. Lett Appl Microbiol 38(5):345-350

43. Ponraj RM, Gokila K, Vasudeo Z (2011) Bacterial decolourization of textile dye-orange. Int J Adv Biotechnol Res 2(1):168-177

44. Arun K, Sawhney R (2011) Identification of Bacillus subtilis subsp. subtilis, "RA-29" a congo red degrader using $16 \mathrm{~S}$ rDNA sequencing. Researcher 3(12):18-22

45. Sudha M, Saranya A, Selvakumar G, Sivakumar N (2014) Microbial degradation of azo dyes: a review. Int Cur Microbiol Appl Sci 3(2):670-690

46. Adinew B (2012) Textile effluent treatment and decolourization techniques - a review. Bulgarian J Sci Educ 21:1140-1146

47. Ekramul Md K, Dhar K, Hossain Md T (2018) Decolorization of textile reactive dyes by bacterial monoculture and consortium screened from textile dyeing effluent. J Gen Eng Biotechnol 16:375-380

48. Singh N, Tuhina V, Rajeeva G (2013) Detoxification of hexavalent chromium by an indigenous facultative anaerobic Bacillus cereus strain isolated from tannery effluent. Afr J Biotechnol 12(10):1091-1103

49. Gadd GM (2000) Bioremedial potential of microbial mechanisms of metal mobilization and immobilization. Curr Opin Biotechnol 11:271-279

50. Shanta N, Bharathi P, Chandramohan D (1993) Effect of heavy metals on marine Bacillus sp. and Flavobacterium sp. Ecotoxicol 2:220-229

51. Beveridge TJ, Doyle RJ (1989) Metal ions and bacteria. Wiley, New York, pp $1-19$

52. Karimpour M, Ashrafi SD, Taghavi K, Mojtahedi A, Roohbakhsh E, Naghipour D (2018) Adsorption of cadmium and lead onto live and dead cell mass of Pseudomonas aeruginosa: a dataset. Data Brief 18:1185-1192. https://doi. org/10.1016/j.dib.2018.04.014

\section{Publisher's Note}

Springer Nature remains neutral with regard to jurisdictional claims in published maps and institutional affiliations. 